\title{
Stubble height standards for Sierra Ne- vada meadows can be difficult to meet
}

\author{
David F. Lile \\ Kenneth W. Tate \\ Donald L. Lancaster \\ Betsy M. Karle
}

\begin{abstract}
Standards for the height of herbaceous vegetation remaining in meadows at the end of the growing season have been, and continue to be, implemented on public grazing lands throughout the Sierra Nevada. Although supporting research is limited, stubble height standards are intended to benefit riparian resources by limiting grazing pressure. This study illustrates how the timing and intensity of defoliation in mountain meadows can affect the stubble height of herbaceous vegetation at the end of the growing season, and compares these findings with current standards. The research also can help livestock operators and public lands managers develop grazing management strategies to meet stubble height standards and conduct local applied research to evaluate the appropriateness of general stubble height standards.
\end{abstract}

\footnotetext{
R iparian meadow systems in California's Sierra Nevada mountains perform an array of critical environmental functions. They provide wildlife habitat, aesthetic value, flood attenuation and maintenance of water quality. Many beef cattle operations rely on vegetation growing on publicly and privately owned meadows for their annual forage budget. During the summer, when low-elevation foothill and valley rangelands are dry and forage quality is low, mountain meadows provide green, highquality forage. Cattle are moved on to mountain meadows annually for a grazing season that typically lasts from
}

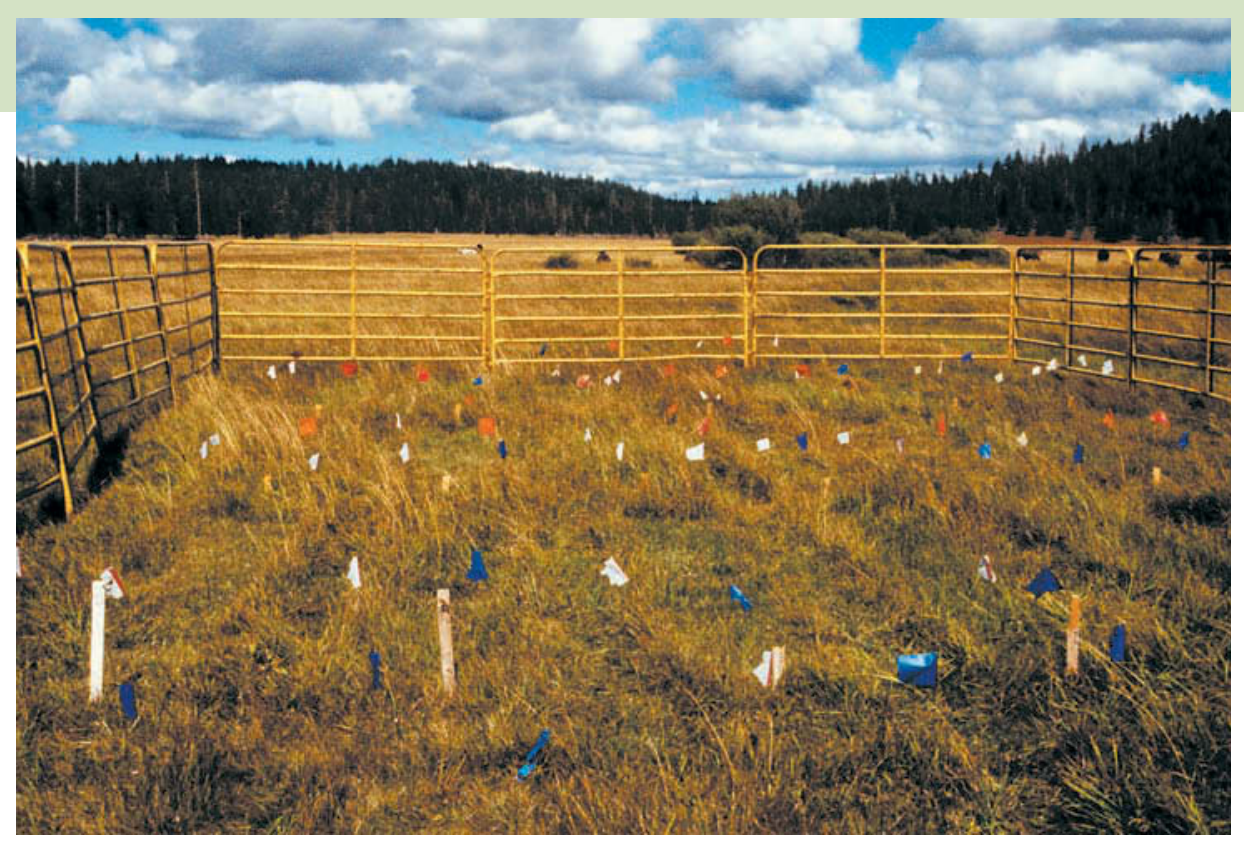

The study site was protected from grazing by cattle during the 3-year study.

early June through late September, depending on the elevation and annual weather conditions.

On public lands, natural resource managers with the United States Forest Service and Bureau of Land Management apply several annual grazing utilization standards that livestock operators must meet as a condition of their grazing permits. There are generally four standards each permittee must address: (1) stubble height, (2) percent stream bank trampling by livestock, (3) percent utilization of woody riparian plants by cattle and (4) percent utilization of herbaceous biomass.

These standards are intended to safeguard riparian resources from damage by excessive livestock grazing. They include height standards for riparian herbaceous plants such as sedges (Carex sp.), rushes (Juncus sp.) and perennial grasses and forbs at the end of the growing season (USDA Forest Service 1991, 1992; USDI Bureau of Land Management 1998). Livestock operators are required to manage the timing and intensity of grazing by their livestock to ensure that herbaceous plants are left at a certain leaf height, referred to as the stubble height, when the livestock leave the area in the fall. There are significant ramifications for the permittee if these stubble height standards are not met. These include a temporary, $25 \%$ reduction in permitted numbers of livestock. Repeated failure can lead to cancellation of the grazing permit (USDA Forest Service 1991, 1992).

Stubble height standards were selected based on the assumption that plant height is (1) a standard easily communicated to managers, (2) easily and quickly measured and (3) directly correlated to the ecological health of specific riparian resources. Anticipated benefits from stubble height standards include enhancement and/or preservation of forage plant vigor, woody riparian plant communities, stream bank stability and floodplain sediment trapping ability. (Clary et al. 1996; Clary and Leininger 2000). However, there is a shortage of research defining the correlation of plant leaf height to the suite of riparian resource values that stubble height standards are expected to safeguard. In a review of the literature, Clary and Leininger (2000) stress that direct experiments to link stubble height standards with riparian resource objectives are limited and that con- 
tinued research is needed. Clary and Leininger also note that stubble height is a short-term management guide for long-term riparian resource objectives and that the stubble height standards should not be thought of as a long-term resource objective

A stubble height of 4 to 6 inches has been widely recommended and enforced as a general grazing standard on public lands for the last decade (USDA Forest Service 1991 and 1992; USDI Bureau of Land Management 1998). In some circumstances, a 3-to-5-inch stubble height has been recommended, depending on stream type and season of grazing (USDA Forest Service 1991, Hall and Bryant 1995). Additional stubble height standards for areas with wildlife species of concern have been proposed, such as a 12-inch standard for meadows within great gray owl habitat areas (USDA Forest Service 2001). On public lands in general, a 4-inch stubble height is required for meadows in "good" condition, often defined as having stable stream banks and a plant community in middle to late seral status. (The "late seral" plant community is composed of "climax" species representing the potential plant community on the site in the absence of disturbance by human activity.) A 6-inch standard is generally required for meadows in "poor" condition, often defined as having unstable stream banks and a plant community in early seral status (USDA Forest Service 2001; USDI Bureau of Land Management 1998). Though measurements are currently taken at the end of the growing season, proposed USDA forest plan amendments are not specific about the time of application of this standard during a season (USDA Forest Service 2001).

The objective of this study was to evaluate how well grazing operators can meet the usual stubble height standards under several typical combinations of timing and intensity of defoliation (by clipping) on a northeastern California mountain meadow. The results should help public-land operators develop grazing management schemes that comply with current stubble height standards. We also hope to illustrate a simple method for local resource professionals to generate site-specific informa- tion on the relationship between grazing schemes and stubble height standards.

Plant defoliation is only one component of livestock grazing, however. This study does not attempt to fully examine the effects of grazing on meadows, which would involve measuring the impacts of livestock hooves, and redistribution of nutrients.

\section{Mountain meadow}

The study was conducted within an 850-acre, moist-to-wet mountain meadow (Clover Valley) located approximately 13 miles north of Westwood in western Lassen County at an elevation of 5,830 feet. Soil type on the site is an aquoll, consisting of loam-to-silt-loam texture with 10-to-20-inch rooting depth, underlain by a gravelly-silty-clay restrictive layer (Kliewer 1994). Dominant plant species on the study site are Nebraska sedge (Carex nebraskensis), rush (Juncus sp.), Kentucky bluegrass (Poa pratensis), tufted hairgrass (Deschampsia caespitosa), native perennial clovers (Trifolium sp.) and buttercup (Ranunculus sp.). Grazing management on the site for the last several decades has been typical of middle-to-late-season moderate use in the region, with stable stream banks and an herbaceous plant community in mid-seral status as determined by USFS Region 5 ecological score cards (USDA Forest Service 2001).

Twenty-eight 2-by-12-foot (24square-foot) plots were placed in a 4- by 7-plot grid with a 2-foot buffer strip between plots. Plots were located within a moist, productive meadow site adjacent to a first-order perennial stream (a headwater stream that flows -year around) flowing through the meadow where plants receive adequate subsurface soil moisture through the growing season from the adjacent stream. The site was fenced to prevent grazing by livestock for the duration of the study.

\section{Clipping treatments}

We simulated grazing by handclipping plots to desired levels (2 and 4 inches) at different times (early and mid-season) during the growing season (June through September). The scope of our project was limited to evaluating how well stubble height standards can be met under different combinations of timing and intensity of defoliation, and for these purposes hand-clipping provided an inexpensive, straightforward and repeatable approach.

Seven combinations of timing and intensity of grazing treatments were replicated four times and randomly applied to the 28 plots during the growing seasons of 1997, 1998 and 1999 (table 1). Each plot received the same treatment each year. All clipped vegetation was removed from the plots at the time of clipping. Clipping times for each year were based on annual weather and growth stage of perennial grasses rather than a set date (table 2). Early-season clipping occurred during the period of active vegetative growth (early June to midJuly) just prior to boot stage (seedhead emergence) of perennial grasses (tufted hairgrass and Kentucky bluegrass). Mid-season clipping occurred from mid-July to mid-August, at the onset of the bloom stage of perennial grasses.

\begin{tabular}{|c|c|}
\hline \multicolumn{2}{|c|}{$\begin{array}{l}\text { TABLE 1. Clipping treatments applied } \\
\text { to plots in Clover Valley }\end{array}$} \\
\hline Treatment & Timing and intensity of clipping \\
\hline E2 & Early-season clipping to 2 inches \\
\hline E4 & Early-season clipping to 4 inches \\
\hline M2 & Mid-season clipping to 2 inches \\
\hline M4 & Mid-season clipping to 4 inches \\
\hline EM2 & $\begin{array}{l}\text { Clipped to } 2 \text { inches both early } \\
\text { and mid-season }\end{array}$ \\
\hline EM4 & $\begin{array}{l}\text { Clipped to } 4 \text { inches both early } \\
\text { and mid-season }\end{array}$ \\
\hline Unclipped & No clipping \\
\hline
\end{tabular}

End-of-season herbaceous plant heights were determined for all plots each year at the time of the first killing frost of the fall. Plant height in the unclipped plots was measured at the time of the early- and mid-season clipping treatment application each year. Midseason plant heights were measured for each of the early-season clipping (E and EM) treatments. At each sample time, five random readings per plot of plant leaf height were taken with a ruler following standard interagency methodology (USDI Bureau of Land Management 1996). Repeated measures analysis of variance was used to determine significance of treatment, year and treatment-by-year interactions. The clipping treatment (seven levels) was the fixed factor, and the end-of-season stubble height was the repeated mea- 
TABLE 2. April 1 snowpack at the Norvell Flat ( 3 miles east of study site, elevation 5,700 feet) and Silver Lake Meadows (4.5 miles west of study site, elevation 6,450 feet), a USFS Lassen National Forest snow survey location, and clipping dates at Clover Valley for 1997, 1998 and 1999

\begin{tabular}{|c|c|c|c|c|}
\hline \multicolumn{3}{|c|}{ April 1 snowpack } & \multicolumn{2}{|c|}{ Clover Valley clip dates } \\
\hline Year & Norvell Flat & $\begin{array}{l}\text { Silver Lake } \\
\text { Meadows }\end{array}$ & Early season & Mid-season \\
\hline \multicolumn{5}{|c|}{$\ldots \ldots \ldots \%$ of average. . . . . . } \\
\hline 1997 & 0.0 & 56 & June 5 & July 16 \\
\hline 1998 & 152 & 145 & July 22 & Aug 13 \\
\hline 1999 & 116 & 127 & June 22 & July 28 \\
\hline
\end{tabular}

surement taken each year $(1997,1998$, 1999) from all 28 plots (7 treatments $\times$ 4 replicates). Pairwise contrasts were used to separate significant treatment and year differences.

\section{Weather and plant growth}

Annual snowfall and the onset of growing season (and therefore clipping dates) varied during the study (table 2). April 1 snowpack in 1997 was below normal, and the onset of the growing season was much earlier than in 1998 and 1999. The 1998 El Niño anomaly provides insight into the effect of grazing timing and intensity on stubble height during a year with high snowfall and a short growing season. Snowpack and growing season onset in 1999 were slightly above average, but approximated long-term average conditions better than 1997 or 1998.

Statistically significant year differences existed in mean unclipped plant leaf height at early season, mid-season and end of season (fig. 1). These data illustrate the effect of variable annual snowfall and onset of growing season on plant height, in the absence of defoliation. The general trend across all years was an increase in plant height from early to mid-season followed by no increase - even a slight decrease - following mid-season as plants set seed and began to senesce. Despite a late onset of the growing season in 1998, there was rapid growth in plant height from the early to middle portion of the growing season. This is likely due to extremely favorable soil moisture conditions following the prolonged melt of the El Niño snowpack.

\section{Treatment effects}

There were significant treatment and year effects, as well as a year-by-treatment interaction effect, on the mean end-of-season stubble height $(P<0.05)$ (fig. 2). Unclipped plots generated a significantly $(P<0.001)$ higher end-of-

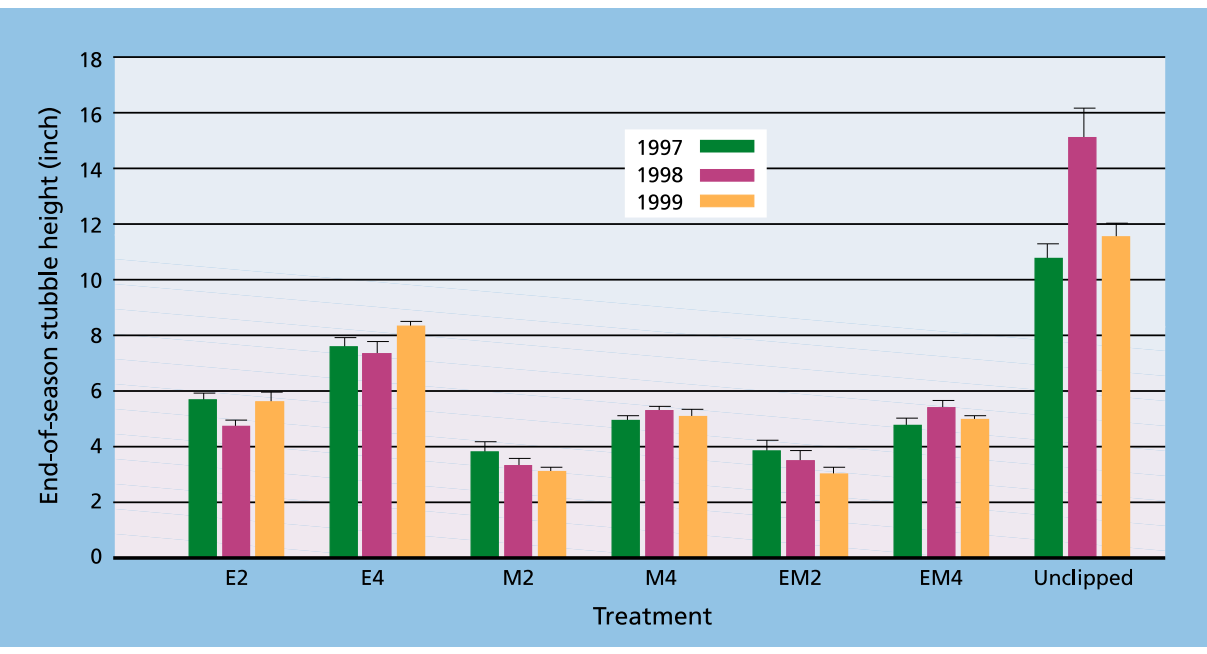

Fig. 2. Mean end-of-season stubble height for seven clipping treatments ( $E=$ early-season clip; $M=$ mid-season clip; $E M=$ early- and mid-season clip; 2, 4 or $6=$ clip height in inches) applied annually to plots in Clover Valley from 1997 to 1999. Sample size for each treatment per year is four. Results can be compared with stubble height standards for meadows in late seral status (4 inches), in early seral status (6 inches), as well as for great gray owl habitat (12 inches). Error bars represent one standard error of the mean.

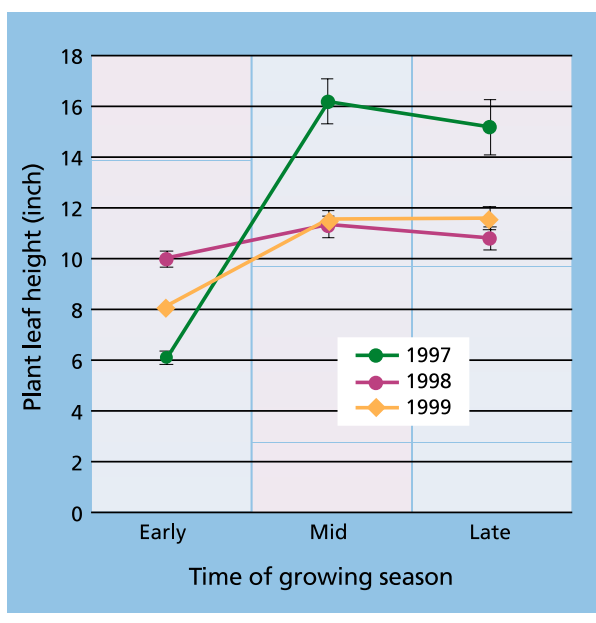

Fig. 1. Mean unclipped treatment plant leaf heights recorded early, mid- and end of season from 1997 to 1999. Sample size for each year is four. These data display potential plant height accumulation on the Clover Valley study site for the study period. Error bars represent one standard error of the mean.

season stubble height compared with all six clipping treatments. The earlyseason, 4-inch treatment (E4) generated a significantly higher $(P<0.05)$ endof-season stubble height than all other clipping treatments. There were no significant differences $(P>0.05)$ in endof-season stubble height between the early-season clip to 2 inches (E2), midseason clip to 4 inches (M4) and earlyand mid-season clip to 4 inches (EM4), but these treatments were significantly different $(P<0.05)$ from all other treatments. The mid-season clip to 2 inches (M2) and early- and mid-season clip to 2 inches (EM2) treatments were not significantly different $(P>0.05)$ from each other, but were significantly different from all other treatments.

The year-by-treatment interaction can be seen by examining the response of end-of-season stubble height across years and across treatments (fig. 2). For example, end-of-season stubble height for the early-season clip only (E2 and E4) was reduced in 1998, while it increased under several other treatments (EM4, M4, unclipped) for the same year. An interesting year effect is the steady reduction in end-of-season stubble height from 1997 to 1999 for treatments with a mid-season clip to 2 inches (M2 and EM2). While this trend could indicate a cumulative treatment effect over time, without additional data on seasonal rainfall patterns and 
total biomass production it is difficult to interpret. For example, more rainfall could have occurred later in the season in 1997 than in 1999.

\section{Public land standards}

Of particular interest to the grazing operator and public lands manager is how end-of-season stubble height generated by the clipping treatments compares with current public lands stubble height standards. These include standards for meadows in early (4 inches) and late (6 inches) seral status, and for locations inhabited by the great gray owl (12 inches) as established by the US Forest Service (USDA Forest Service 1991, 1992, 2001).

Unclipped plots achieved the 4- and 6-inch stubble height standards in all 3 study years. However, the unclipped plots achieved the 12-inch standard for great gray owl areas only in the $1998 \mathrm{El}$ Niño year. This raises questions about the appropriateness of this particular standard for similar meadows in the region. The 12-inch standard may not be achieved even with the complete removal of livestock. There is a need for continued investigation of stubble height standards by regions and across different site conditions (elevation, moisture regime, soil type, and so on).

Treatment plots with early-season clipping to 2 and 4 inches (E2 and E4) met the 4-inch end-of-season stubble height standard across all years. However, only plots receiving the E4 clipping treatment achieved the 6-inch stubble height standard. In fact, E4 was the only clipping treatment in any year that met the 6-inch standard recommended on low seral meadows (fig. 3). Significant recovery of plant height occurred prior to mid-season (seed set in perennial grasses) in plots clipped in the early season (prior to boot stage in perennial grasses). Little, if any, recovery of plant height occurred during the late growing season on these plots. This indicates that early season grazing benefits the grazing operator by allowing sufficient time prior to seed set for the plant height to recover after grazing.

Clipping treatments that include a mid-season clip to 2 inches (M2 and EM2) did not achieve the 4-inch stubble height standard due to the lim-

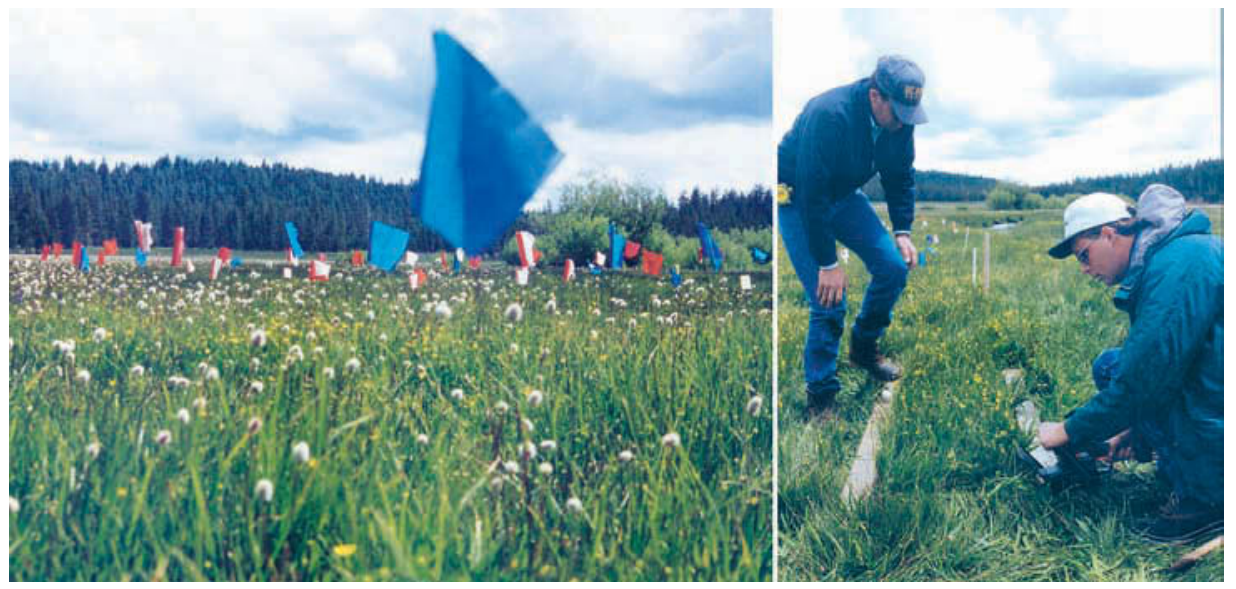

Left, Vegetation at the study site was a mixed community composed of sedges, grasses, rushes, native clovers and other forbs. Right, Specialist Tate and advisor Lile hand-clip one of 28, 7-by-12-foot plots. Clipped vegetation was removed from the plot.

ited regrowth potential of herbaceous meadow vegetation following seed set. Even during 1998, there was essentially no recovery of stubble height following mid-season clipping. To graze midseason, the intensity of grazing must not lower plant leaf height below the standard for the site, because very little recovery can be expected following seed set.

The importance of carefully managing mid-season grazing intensity is also illustrated by the results for the midseason clip to 4 inches (M4) and the early- plus mid-season clip to 4 inches (EM4). Plots receiving these treatments achieved the 4-inch standard, but due to the slight regrowth they experienced after mid-season clipping, they were not able to attain the 6-inch stubble height standard recommended for meadows in early seral stage. In order to meet a 6-inch standard, mid-season grazing must leave 6 inches of stubble height.

\section{Grazing options}

While the difference between a 4- and 6-inch end-of-season stubble height standard seems slight on paper, only one clipping scheme tested (early season clip to 4 inches) in this project achieved the 6-inch standard, while four of the schemes tested achieved a 4-inch standard. Using Clover Valley as a case study, the manager has only two options to achieve a 6-inch stubble height standard. One, the manager could prevent livestock from grazing below 6 inches during the mid- to late season, only grazing the pasture in the mid- to late season. Two, the manager could graze to 4 inches in the early season, remove livestock for the remainder of the summer and rely on within-season regrowth to achieve a 6-inch end-ofseason stubble height. Under either option, the forage below 6 or 4 inches must be considered unavailable and the livestock carrying capacity of the pasture (available annual forage) recalculated accordingly. The majority of above ground herbaceaous plant biomass (forage) is located in the lower $50 \%$ of plant height, so stubble height standards that exclude this forage significantly reduce

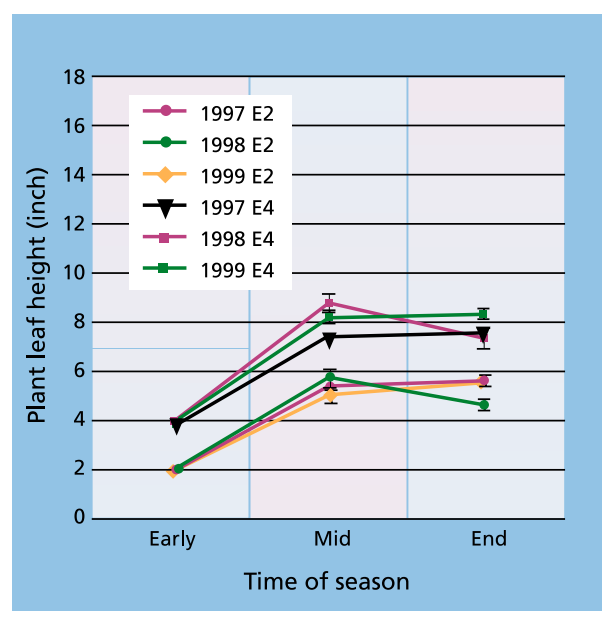

Fig. 3. Mean plant height recovery following early-season clipping treatments to 2 inches (E2) and 4 inches (E4) applied annually to plots in Clover Valley from 1997 to 1999. Sample size for each treatment per year is four. These data illustrate the minimal recovery of plant height that occurs following mid-season. Error bars represent one standard error of the mean. 
available annual forage.

While early season grazing appears to provide the best chance of achieving stubble height standards while using the most available forage, this grazing scheme could have negative effects on soils and stream banks because of wet conditions and the composition of plant species in the early growth stage of the plant at defoliation. Potentially, the negative impacts of early season grazing designed to achieve a set stubble height standard might exceed the negative effects of other grazing schemes that do not achieve the stubble height standard. Where early season grazing is the only option to achieve standards, restrictions on early season grazing (such as a grazing permit start date of mid-July) would essentially make little or no forage available to the grazing manager, and almost assure noncompliance with grazing permit requirements.

Given the limitations that stubble height standards impose on the grazing options available to managers, it is important to note that stubble height standards are an annual grazing management tool designed to achieve general riparian resource protection, not a long-term management goal (Clary and Leininger 2000). If one of the intentions of stubble height standards is to allow grazing to continue in an economically and ecologically sustainable manner, significant research and revision of these standards seems warranted. The direct links between herbaceous stubble height and specific riparian resource goals are not clearly illustrated in the published scientific literature, indicating the need for long-term research on the relationship between annual stubble height standards and the condition and trend of riparian systems. The significant effect of annual weather patterns on plant leaf height in the absence of defoliation should also be factored into the annual application of stubble height standards on these dynamic meadow systems.

D.F. Lile is Natural Resources and Livestock Advisor, UC Cooperative Extension, Lassen County; K.W. Tate is Rangeland Watershed Specialist, UC Davis; D.L. Lancaster is Natural Resources Advisor, UC Cooperative Extension, Modoc County; B.M. Karle is Research Associate, UC Davis.

\section{References}

Clary WP, Leininger WC. 2000. Invited paper: Stubble height as a tool for management of riparian areas. J Range Management 53:562-73.

Clary WP, Thorton Cl, Abt SR. 1996. Riparian stubble height and recovery of degraded streambanks. Rangelands 18:137-40.

Clary WP, Webster BF. 1990. Riparian grazing guidelines for the intermountain region. Rangelands 12:209-12.

Hall FC, Bryant L. 1995. Herbaceous stubble height as a warning of impending cattle grazing damage to riparian areas. USFS Gen Tech Rep PNW-GTR-362. 10 p.

Kliewer, GF. 1994. Soil survey of the Lassen National Forest and surrounding area. USFS-PSW.

USDA Forest Service. 1991. Land and resource management plan, Modoc National Forest. USFS-PSW. Appendix T-4.

\section{Wine and cheese}

California's wine drinkers and cheese lovers are going upscale: In the last 10 years wine drinkers have increasingly favored premium wines by reaching for bottles priced $\$ 7$ and over rather than the $\$ 3$-a-bottle jug wines. At the same time, diners in fine restaurants are being treated to dishes prepared with specialty cheeses and courses featuring simply cheese - artisan and handmade. In the next issue of California Agriculture, UC scientists examine trends in the state's wine consumption and the factors that prompt Californians to purchase artisan cheese.

\section{ALSO COMING UP:}

$\nabla$

Consumer attitudes about genetically modified foods

$$
\nabla
$$

The economics of organophosphate insecticide

Managing walnut pests

USDA Forest Service. 1992. Land and resource management plan, Lassen National Forest. USFS-PSW. $p$ 4-23.

USDA Forest Service. 2001. Sierra Nevada forest plan amendment, final environmental impact statement. Vol. 4. USFS-PSW. Appendix D1-17 and D1-37.

USDI Bureau of Land Management. 1996. Utilization studies and residual measurements. Interagency technical reference. BLM/ RS/ST-96/004+1730. p 51-4.

USDI Bureau of Land Management. 1998. Rangeland health standards and guidelines for California and northwestern Nevada, final environmental impact statement. BLM/ CA/ES-98/005+4100. p 65.

\section{Visit California Agriculture on the Internet:}

\section{http://danr.ucop.edu/calag/}

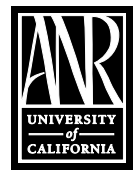

calag@ucop.edu

Phone: (510) 987-0044

Fax: (510) 465-2659

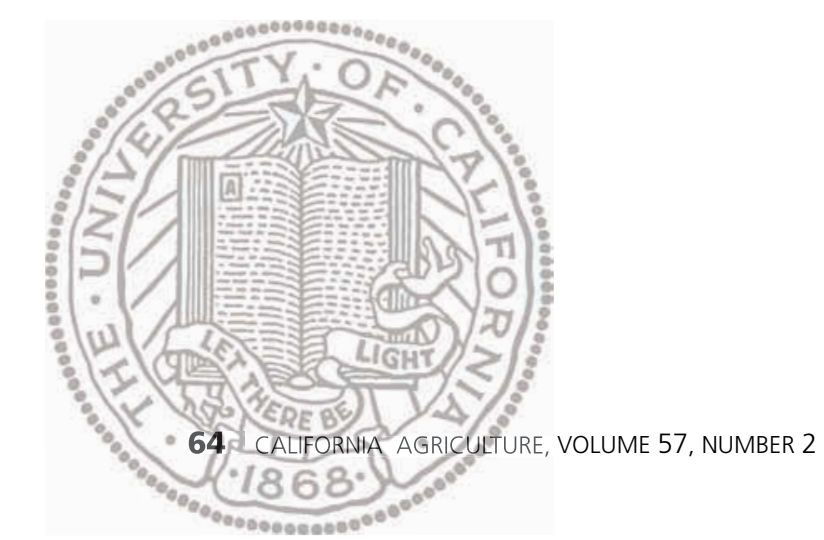

